\title{
Recognition of Linguistic Characteristics of Bilingual Students when Teaching Japanese at North-Eastern Federal University
}

\author{
Sardana Efimova* \\ North-Eastern Federal University named after M.K. Ammosov, 58 Belinsky str., Yakutsk (Republic of Sakha), 677000, Russian \\ Federation
}

\begin{abstract}
The article justifies the need to take into account the linguistic characteristics of bilingual students from among the indigenous inhabitants of the Republic of Sakha (Yakutia) when teaching the Japanese language at the North-Eastern Federal University named after M.K. Ammosov. The purpose of this study is to analyze the linguistic phenomena of the Japanese and Yakut languages for the effective development of foreign language communicative competence of students. The author of the study revealed a contradiction at the methodological level between the need to train specialists with knowledge of the Japanese language from among the indigenous peoples of Yakutia and the lack of a methodology that takes into account the linguistic characteristics of bilingual students. The research methods were theoretical and empirical methods. Due to the fact that the key feature of teaching foreign languages in the Republic is bilingualism of students, the author of the article analyzed scientific literature on the topic of bilingualism, justified the need to take into account bilingualism of students when teaching Japanese in the national Republic. Difficulties arising in the study of the Japanese language are considered. As a result of the study, the grammatical, lexical and phonetic phenomena of the Japanese language, which have similarities in the Yakut language, have been identified, it is proposed to explain these phenomena in the process of teaching the Japanese language based on the Yakut language.
\end{abstract}

\section{Introduction}

As history shows, the problem of man and such concepts as language, consciousness, thinking, communication, culture are fundamental for philosophical thought. Ancient Greek philosophers considered issues related to the relationship of language, speech and thinking, as well as issues of interpersonal relations arising from the appeal to the problem of man. The first Greek teachers, the so-called sophists, characterized the word as a bearer of conviction, belief and suggestion, developing the principles of rhetoric as the art of speech. Socrates, the founder of moral philosophy - ethics, argued that there is knowledge in the human mind, which manifests itself in the course of dialogue as a way of reasoning, thus, dialogue is a means of human self-knowledge; Plato wrote that a person needs others, implying communication, and singled out such methods of transmitting information as speech and writing [1]. Aristotle first used the term communication, considering it as a means necessary for people to live together [2]. Thus, the ancient philosophers laid the basis of communication studies and pedagogy, justifying the intrinsic value of man and communication, and their works acted as a means of transferring knowledge to future generations.

F. Schleiermacher [3], and then him G.G. Shpet [4], M. Heidegger [5], H.G. Gadamer [6] and other philosophers developed the ideas of hermeneutics proposed by ancient philosophers, where understanding acts as an important component and goal of communication. According to F. Schleiermacher, to comprehend the meaning of the text, it is necessary to concentrate on all aspects of the language: grammar, syntax, and vocabulary. G.G. Shpet argued that only with the help of language does a person know and understand the surrounding reality. M. Heidegger believed that understanding is a way of human being, language is the house of being, which acts as a mediator between the world of things and man. According to H.G. Gadamer, language is the house of being and the way of being, i.e. language influences thinking, creating a national picture of the world. His theory substantiates the idea that understanding is a universal property of being, since a person learns the world through understanding people, nature, history, etc. Hermeneutics considers language as a tool, and consciousness as a method of understanding, in this regard, the concept of linguistic

*Corresponding author: sardana_efimova @ mail.ru 
consciousness appears, which serves as the basis for linguistic pictures of the world of different peoples. Thus, bilingual students from among the indigenous inhabitants of Yakutia have their own linguistic picture of the world, which requires consideration when studying Japanese at universities.

In Russia, the interest in the study of the social and cultural phenomenon of Japan has been observed since the 90 s of the twentieth century, as a result of which the departments of Japanese language and culture were established in Russian universities. The experience in teaching Japanese in the Republic of Sakha (Yakutia) on the basis of Yakut State University as a second foreign language is almost 30 years since 1991 and as the main foreign language - since 2000. Philology and Regional Studies of the North-Eastern Federal University trains bachelors and masters developing their knowledge of Japanese and literature in the field of Philology. Japanese as a second foreign language is studied by bachelors of the Department of History, Medical Institute, Department of Translation of the Institute of Foreign Philology and Regional Studies, as well as undergraduates in the field of Linguistics of the Institute of Foreign Philology and Regional Studies. Studying the Japanese language provides students with the opportunity to join the conceptual system of the Japanese people, enriches their personality. They learn another culture and use this knowledge in their life.

\section{Materials and Methods}

The purpose of this study is to analyze the linguistic phenomena of the Japanese and Yakut languages for a positive transfer from the native language when teaching Japanese to bilingual students at the initial stage. In accordance with the goal, the research tasks were identified: to determine the scientific and theoretical foundations of bilingualism; to analyze the linguistic phenomena of the Japanese and Yakut languages for a positive transfer from the native language to the Japanese language.

The research methods: theoretical: analysis of literature on the research topic; systematization; empirical: generalization of the experience of teaching Japanese at university; comparative analysis.

The key features of teaching foreign languages in the Republic of Sakha (Yakutia) include the natural YakutRussian bilingualism of the indigenous inhabitants of the Republic, which was developed as a result of cultural, historical aas well as social and political factors. Taking into account the Yakut-Russian bilingualism in teaching foreign languages in the Republic of Sakha (Yakutia) is justified by such scientists as G.M. Parnikova [7], M.M. Fomin [8]/ et.el. The studies of bilingualism are devoted to the work of many Russian scientists who consider the conditions and problems of bilingualism development, its typology, linguistic interference, etc. Scientists agree that bilingualism contributes to the development of a meaningful attitude to language and develops attention to the details and structure of languages, recognition of polysemy, etc. E.M. Vereshchagin classifies bilingualism according to the following criteria: age; quality of actions performed on the basis of bilingualism; correlation of speech mechanisms; communicative source of development; way of communication between speech and thinking, an indicator of communicative activity [9]. A.A. Zalevskaya classifies bilingualism according to the nature of the conditions for language acquisition - natural and artificial (educational) bilingualism; by the nature of the processes used in the process of mastering and using the second language; by products as a result of these processes in language acquisition [10]. L.V. Shcherba distinguishes pure and mixed bilingualism: in the first case, the social groups underlying bilingualism are mutually exclusive; in the second case, the groups cover each other; in special cases, bilinguals of the second type create a form of language where each idea has two ways of expression [11].

Thus, having analyzed the theoretical literature on the research topic, the conclusion was made that it is necessary to take into account the linguistic characteristics of bilingual students studying Japanese at the North-Eastern Federal University.

Besides, within the framework of our research, we consider it necessary to review the features of the Japanese language and the difficulties associated with its study. Researchers of the Japanese language (V.M. Alpatov [12], E.V. Maevsky [13], A.A. Pashkovsky [14], etc.) believe that the Japanese language is difficult to learn due to such specific features as hieroglyphic writing, stylistics, grammar that is different from European, strict rules of linguistic etiquette, etc. Linguists also point out that the Japanese start their statement with something general transitioning to something particular, and the sentence ends with a subjective assessment of what was said in the form of a verb - with a given sentence structure, the speaker's attitude to the subject, his real intentions are unknown, which causes difficulties in learning Japanese [15]. The analysis of the phonetic-ideographic system of Japanese writing indicates that a word in the Japanese language consists of three hieroglyphs on average, which have from two to ten readings [16]. V.M. Alpatov notes that the difficulties associated with hieroglyphs also appeared after the introduction of the hieroglyphic minimum in Japan in 1946, because the usual functions of hieroglyphs and two types of alphabets hiragana and katakana were disrupted [12]. The imperfection of this hieroglyphic minimum was the reason for its replacement by a new minimum in 1981, which includes 1945 hieroglyphs, which is 95 more than the previous one. Thus, the hieroglyphic minimum influenced the functioning of the Japanese language, as a result of which the free reading of fiction of the late 19th and early 20th centuries is difficult for modern Japanese.

Next, the features of the Japanese literary language are considered, which cause certain difficulties in learning Japanese. In modern Japan, there are four variants of the literary language: book-written, bookoral, spoken-oral and spoken-written [12]. As Russian scientists note, the length of sentences, lexical and syntactic features are more pronounced in the book 
versions of the Japanese language, due to certain peculiarities, it is impossible to directly translate the book-written version of the language into the book-oral version, which is primarily due to the functioning of a large number of homonyms in Japanese. In written speech, an abundance of kango homonyms is noted, which are written in hieroglyphs; in oral speech, native Japanese wago words are used. In addition, the researchers note gender differences in speech characteristic of the Japanese language, which are relevant in the book-oral version of the language. Besides, the difference between the book-written and book-oral variants of the language is presented in the

system of forms of politeness. The spoken-oral and spoken-written versions differ from the corresponding book versions in less syntactic complexity, frequent use of ellipsis and other use of forms of politeness. According to I.I. Bass ellipsis, which is observed at various language levels - writing, phonetics, grammar, vocabulary - is one of the main features of the Japanese language, and for the correct understanding of the statement, background knowledge, the ability to associate, the ability to draw conclusions, etc. are required. [17].

\section{Results and Discussion}

Table 1. Examples Japanese grammar based on the Yakut language

\begin{tabular}{|c|c|c|c|}
\hline Grammar & Japanese & Yakut language & Translation \\
\hline No gender & $\begin{array}{l}\text { これ } \\
\text { それ }\end{array}$ & $\begin{array}{c}\mathrm{bu} \\
\mathrm{ol}\end{array}$ & this, that \\
\hline Demonstrative pronouns & $\begin{array}{l}\text { この } \\
\text { その } \\
\text { あの }\end{array}$ & $\begin{array}{l}\text { bu } \\
\text { iti } \\
\text { ol }\end{array}$ & $\begin{array}{l}\text { this } \\
\text { this } \\
\text { that }\end{array}$ \\
\hline Negative pronouns & $\begin{array}{l}\text { だれも } \\
\text { なにも } \\
\text { どこ㫣 }\end{array}$ & $\begin{array}{l}\operatorname{kim} \underline{\mathrm{da}} \\
\text { tuoh } \underline{\mathrm{da}} \\
\text { hanna } \underline{\mathrm{da}}\end{array}$ & $\begin{array}{c}\text { no one } \\
\text { nothing } \\
\text { nowhere }\end{array}$ \\
\hline Predicate at the end of a sentence & 明日手紙を書きます & $\begin{array}{c}\text { Sarsyn } \\
\text { min suruk } \\
\text { suruiyom. }\end{array}$ & $\begin{array}{c}\text { Tomorrow I will write a } \\
\text { letter. }\end{array}$ \\
\hline Interrogative particle after predicate & ここはだれがいますか。 & $\begin{array}{l}\text { Manna kim baar } \\
\text { duo? }\end{array}$ & Who is there? \\
\hline Negative form of adjectives & $\begin{array}{l}\text { きれいじゃない } \\
\text { よくない }\end{array}$ & $\begin{array}{l}\text { yraaha suoh } \\
\text { uchugeye suoh }\end{array}$ & $\begin{array}{l}\text { unclean } \\
\text { bad }\end{array}$ \\
\hline The affix indicates time, negation, etc. & $\begin{array}{l}\text { すわりなさい } \\
\text { すわるな }\end{array}$ & $\begin{array}{l}\text { olororui } \\
\text { oloruma }\end{array}$ & $\begin{array}{c}\text { sit down } \\
\text { don't sit down }\end{array}$ \\
\hline Service verbs: completeness of action & 食べてしまった & sien kebistim & ate \\
\hline Service verbs: try to do & たべてみる & sien korobun & I'll try to eat \\
\hline Service verbs: goal setting & 行くようにします & baraary gynabyn & going to go \\
\hline Service verbs: beginning of action & 子供は寝始める & ogo utuian erer & $\begin{array}{l}\text { a baby started to fall } \\
\text { asleep }\end{array}$ \\
\hline Participial definition before the defined & 書いている人 & suruyar kihi & the person who writes \\
\hline Purpose participle & 食べにきました & ahaary kellibit & came to eat \\
\hline $\begin{array}{c}\text { Postpositions of the Japanese language - affixes } \\
\text { of the Yakut language }\end{array}$ & 飛行機で & samolyotunan & by plane \\
\hline Location: noun place / postposition after object & $\begin{array}{l}\text { 箱の中に } \\
\text { 家の上に }\end{array}$ & $\begin{array}{l}\text { jyaahyk ihiger } \\
\text { j'ie urduger }\end{array}$ & $\begin{array}{l}\text { inside the box } \\
\text { over the house }\end{array}$ \\
\hline
\end{tabular}

As a result of analysis the following contradiction in methodology as regards the didactics and practical work of universities when teaching bilingual students the Japanese language in the Republic of Sakha (Yakutia) is recognized: between the need to train specialists who have knowledge of Japanese among the indigenous peoples of Yakutia and the lack of methodology that takes into account the linguistic characteristics of bilingual students. The revealed contradiction determined the problem of this study: The study of which grammatical, lexical and phonetic phenomena of

Table 2. Examples of Japanese vocabulary based on the Yakut language

\begin{tabular}{|l|c|c|c|}
\hline Vocabulary & Japanese & Yakut & Translation \\
\hline
\end{tabular}

the Japanese language for bilingual students of the RS (Y) language will be more effective when relying on the Yakut language?

As a result of the study, the grammatical phenomena of the Japanese and Yakut languages were revealed, the explanation of which is considered more effective when relying on the Yakut language, due to the fact that these languages are agglutinative. As well as lexical and phonetic phenomena of the Japanese language, which have similarities in the Yakut language and which do not exist in the Russian language.

\begin{tabular}{|c|c|c|c|}
\hline & & language & \\
\hline Count & $\begin{array}{c}\text { ビゅういち } \\
(10 \text { and } 1)\end{array}$ & $\begin{array}{c}\text { uon biir }(10 \\
\text { and 1) }\end{array}$ & $\begin{array}{c}\text { eleven } \\
\text { twelve }\end{array}$ \\
\hline
\end{tabular}




\begin{tabular}{|c|c|c|c|}
\hline & $\begin{array}{c}\text { じゅうに } \\
\text { (10 and } 2) \\
\text { etc. up to } 19\end{array}$ & $\begin{array}{l}\text { uon ikki (10 } \\
\text { and 2), etc. } \\
\text { up to } 19\end{array}$ & etc. up to 19 \\
\hline Kinship & $\begin{array}{c}\text { あに } \\
\text { おとうと } \\
\text { あね } \\
\text { いもうと }\end{array}$ & $\begin{array}{c}\text { ubai } \\
\text { ini } \\
\text { ejiei } \\
\text { baltym }\end{array}$ & $\begin{array}{c}\text { older } \\
\text { brother } \\
\text { younger } \\
\text { brother } \\
\text { elder sister } \\
\text { little sister }\end{array}$ \\
\hline $\begin{array}{l}\text { Month names: } \\
5 \text { months } \\
\text { according to } \\
\text { the Yakut } \\
\text { chronology - } \\
\text { according to } \\
\text { the ordinal } \\
\text { number }\end{array}$ & $\begin{array}{l}1 \text { 月月 } \\
1 \text { 1月 } \\
12 \text { 月 } \\
1 \text { 月 } \\
2 \text { 月 }\end{array}$ & $\begin{array}{l}\text { altynny } \\
\text { (sixth) } \\
\text { setinnyi } \\
\text { (seventh) } \\
\text { ahsynny } \\
\text { (eighth) } \\
\text { tohsunnyu } \\
\text { (ninth) } \\
\text { olunnyu } \\
\text { (tenth) }\end{array}$ & $\begin{array}{l}\text { October } \\
\text { November } \\
\text { December } \\
\text { January } \\
\text { February }\end{array}$ \\
\hline $\begin{array}{c}\text { Date: month, } \\
\text { day }\end{array}$ & 1月 25 日 & $\begin{array}{l}\text { tohsunnyu } \\
25 \text { kune }\end{array}$ & $\begin{array}{l}\text { The 25th of } \\
\text { January }\end{array}$ \\
\hline
\end{tabular}

Table 3. Examples of Japanese phonetics based on the Yakut language

\begin{tabular}{|c|c|c|}
\hline Phonetics & Japanese language & $\begin{array}{c}\text { Yakut } \\
\text { language }\end{array}$ \\
\hline $\begin{array}{c}\text { Vowel } \\
\text { ptrolongation }\end{array}$ & $\begin{array}{c}\text { おばさん (obasan) } \\
\text { aunt }- \text { おばあさん } \\
\text { (obaasan) }\end{array}$ & $\begin{array}{c}\text { at (horse) - aat } \\
\text { (name) } \\
\text { ur (build-up) - }\end{array}$ \\
\hline
\end{tabular}

\section{Conclusion}

Thus, the goal and objectives of the study were achieved. In the course of this study, the linguistic difficulties encountered by bilingual students when studying Japanese were categorized - phonetics: accentuation, intonation, presence of sounds that have no analogues in the Yakut and Russian languages; hieroglyphic writing: one hieroglyph can have 8 ways of reading, consist of 24 lines, similar elements in different hieroglyphs; grammatical structure different from European and Turkic languages, which is characterized by a large number of postpositions, ellipsis, vocabulary, direction of action, forms of politeness; vocabulary characterized by multiple homonymy, onomatopoeia, a large number of cliché phrases, differences in gender speech, variant spelling of words; stylistic diversity: four variants of the literary language (book-written, book-oral, spoken-oral and spoken-written); three conversational styles (neutral, neutral-polite, polite-polite); reading: no inter-word spaces, vertical organization of the text from right to left.

As a result of literature analysis on the topic of the research, the account of bilingualism of students in teaching the Japanese language was justified. When using a comparative analysis, the grammatical, lexical and phonetic phenomena of the Japanese language was identified, which have similarities in the Yakut language. In the course of generalizing the experience of teaching bilingual students the Japanese language at the university, a more effective understanding of these phenomena was noticed as a result of categorizing the linguistic phenomena of the Japanese and Yakut languages. The authors of the article have prepared a

\begin{tabular}{|c|c|c|}
\hline & $\begin{array}{c}\text { grandmother } \\
\text { おL゙さんお (ojisan) } \\
\text { uncle - おじいさん } \\
\text { (ojiisan) grandfather }\end{array}$ & uur (put) \\
\hline $\begin{array}{l}\text { Prolongation of } \\
\text { the stressed vowel } \\
\text { in borrowed } \\
\text { words }\end{array}$ & $\begin{array}{l}\text { ゼミナール } \\
\text { (zeminaaru) } \\
\text { ヤクーツク } \\
\text { (yakuutsuku) }\end{array}$ & $\begin{array}{c}\text { kylaas } \\
\text { harand } \underline{\text { aaas }}\end{array}$ \\
\hline $\begin{array}{l}\text { Doubling } \\
\text { consonants }\end{array}$ & $\begin{array}{c}\text { がっこう (gakkoo) } \\
\text { やっと (yatto) } \\
\text { マップ (mappu) } \\
\text { あんない (annai) }\end{array}$ & $\begin{array}{l}\text { ikki } \\
\text { yttar } \\
\text { oloppos } \\
\text { manna }\end{array}$ \\
\hline $\begin{array}{c}\text { Sound O - only } \\
{[\mathrm{o}]}\end{array}$ & $\begin{array}{c}\text { ともだち } \\
\text { (tomodachi) }\end{array}$ & oloppos \\
\hline $\begin{array}{c}\text { In borrowed } \\
\text { words, consonants } \\
\text { in the middle of a } \\
\text { word are } \\
\text { interspersed with } \\
\text { vowels } \\
\end{array}$ & $\begin{array}{c}\text { Class - クラス } \\
\text { (kurasu) class }\end{array}$ & $\begin{array}{l}\text { [vedro] - } \\
\text { biedere }\end{array}$ \\
\hline $\begin{array}{l}\text { Vocalization of } \\
{[\mathrm{v}] \text { sound in }} \\
\text { borrowed words }\end{array}$ & $\begin{array}{c}\text { Wave-ウエーブ } \\
\text { (ueebu) wave }\end{array}$ & $\begin{array}{c}\text { [vedro] - } \\
\text { biedere }\end{array}$ \\
\hline
\end{tabular}

curriculum for the academic discipline Workshop on the main language (Japanese), in the implementation of which the results of the study are used, which ensured a positive transfer of linguistic phenomena from Yakut to Japanese when teaching bilingual students from among the indigenous inhabitants of the Republic who study Japanese at university.

\section{References}

1. E.N. Orlov, E.F. Litvinova, M.V. Sabinina, E.K. Watson, Socrates. Plato. Aristotle. Hume. Schopenhauer: Biogr. Narratives (Ural, Chelyabinsk, 1995)

2. Aristotle, Rhetoric (Labirint, Moscow, 2000)

3. F. Schleiermacher, Hermeneutics (Evropeisky Dom, St. Petersburg, 2004)

4. G.G. Shpet, Philosophy and Psychology of Culture (Nauka, Moscow, 2007)

5. M. Heidegger, Being and Time (Folio, Kharkiv, 2003)

6. H.-G. Gadamer, Truth and Method: Fundamentals of Philosophy Hermeneutics (Progress, Moscow, 1988)

7. G.M. Parnikova, Regional-Ethnic Approach to Foreign Language Education (Sakhaada, Yakutsk, 2018)

8. M.M. Fomin, Comparative Analysis of Lexical and Grammatical Systems of the English, Russian and Yakut languages (Yakutsk State University, Yakutsk, 1987)

9. E.M. Vereshchagin, V.G. Kostomarov, Language and Culture: Linguistic and Regional Studies in 
Teaching Russian as a Foreign Language (Russky Yazyk, Moscow, 1990)

10. A.A. Zalevskaya, Questions of Psycholinguistics, 10, 10 (2009)

11. L.V. Shcherba, Language System and Speech Activity (Editorial URSS, Moscow, 2004)

12. V.M. Alpatov, Japan: Language and Culture (Yazyki Slavyanskih Kultur, Moscow, 2008)

13. E.V. Mayevsky, Graphic Stylistics of the Japanese Language (Muravei-Guide, Moscow, 2000)

14. A.A. Pashkovsky, Features of Japanese Vocabulary (Nauka, Moscow, 1971)

15. L.T. Nechaeva, Scientific and Methodological Foundations of the Structure and Content of Japanese Textbooks for Russian Speakers (2000) https://viewer.rusneb.ru/ru/000200_000018_RU_ NLR_bibl_264230?page $=3 \&$ rotate $=0 \&$ theme $=$ wh ite

16. S.V. Neverov, Social and Linguistic Practice of Modern Japan (KomKniga, Moscow, 2005)

17. I.I. Bass, Topical Issues of Japanese and General Linguistics: In Memory of I.F. Vardul (Vostochnaya Literatura, Moscow, 2005) 